BULLETIN OF KYIV NATIONAL UNIVERSITY OF CULTURE AND ARTS Series in Management of Social and Cultural Activity: Scientific Journal, Volume 2 (2019), Number 2, pp. 62-76

doi: https://doi.org/10.31866/2616-7573.2.2019.190622

ISSN 2616-7573 (Print), ISSN 2617-1104 (Online)

UDC: 005.732

JEL Classification: M10, M12, M14, Z11

Received: $16 / 10 / 2019$

\title{
Tatiana Povalii
}

Senior Lecturer, PhD, Sumy State University, 2, Rymskogo-Korsakova st., 40007 Sumy, Ukraine; e-mail: tatianapovaliy@gmail.com; orcid id: https://orcid.org/0000-0001-5821-9775; tel.: +380 664847895

\section{Professional Profile of the Nowadays Manager of the Sociocultural Activity}

\begin{abstract}
Introduction. The relevance of management in the sociocultural field keeps growing nowadays. There's a need to explore the professional profile of the manager involved in this process, whose activity is to control the storing and distributing of the cultural assets. Purpose and methods. The purpose is a theoretical analysis, systematization and generalization of the scientific research on the professional profile of the sociocultural activity manager, which allows to meet the professional demands more effectively and survive at the extremely competitive market. General scientific analysis, synthesis, systematization and generalization of the theoretical knowledge have been applied during the research, as well as the experimental terminological analysis, situational, structural, functional and comparative methods. Results. The key duties and functions of the nowadays sociocultural activity manager have been explained. The following components of their professional competence have been defined: sociocultural, technological, managing, marketing, cultural, humanitarian, psychological and politic knowledge; general and special skills, general scientific and professional experience. The personal traits (leadership, will, moral) and communication capabilities (informative, interactive, perceptive) have been revealed. Conclusions and discussion. The scientific novelty of the obtained results lies in clarification of the notion of the "manager of sociocultural activity" and revealing manager's professional profile from the perspective of his duties, functions, professional competence, personality traits, communication capabilities and roles, while practical application lies in the direct use of the professional profile by the managers, operating in the sociocultural field, taking into account their individual practice.
\end{abstract}

Keywords: manager, sociocultural activity, personal profile, competence, communication. 


\section{Introduction}

The problem formulation. In the period of social relations modernization there has arisen not only a real need, but also the possibility of transition from subject-object to subject-subject principles of relations in the sphere of culture. The social need for creating the maximum number of new institutions for sociocultural activities of citizens has increased. This was reflected, in particular, in emergence of many fundamentally new institutions, enterprises, organizations of sociocultural sphere, which allowed to expand the range of content, forms and types of cultural and leisure activities. An important condition for activation of these processes was emergence of specialists in sociocultural activity management.

Due to significant socio-economic transformations in the system of market relations, the essence of the sociocultural activity manager's profession must be manifested through an ever-increasing set of skills, functions and competences. Our time realities require a new type of specialist who will not only have traditional knowledge and skills, but also understand innovative and entrepreneurial activities. It is important to have a professional image, i.e. a mental picture, an idea about a particular sphere. And since the sociocultural activity manager's profession has relatively recently entered the labor market and is not sufficiently revealed by the scientific community, it is necessary to create its professional profile, which is extremely important for employment.

The content the sociocultural sphere manager's activity includes management of selection, storage, production and dissemination of cultural values. A modern manager must have knowledge on organization and financial control, marketing and staffing. However, that is not all, nowadays there is some minimum of different characteristics for the modern manager of sociocultural activity. That is why the professional profile of the sociocultural activity manager, which envisages analysis of the works of domestic and foreign scientists in the field of management and sociocultural activity, is of particular importance.

State study of the problem. The issues of studying the professionalism of a modern manager of sociocultural activity in its various aspects were investigated by domestic and foreign scientists. In particular, the studies of T. Hryhorchuk (2018), I. Ignatova, T. Donskaia, N. Pliushkina (2016), N. Kochubej (2015) and others need special attention.

A number of works by such scientists as V. Adolf (1998), V. Lokshyn (2011), L. Severova (2014) and others are devoted to determining the essence, structure and content of professional competence of specialists of a sociocultural profile. Psychological approaches to the study of the personality of the modern sociocultural activity manager were developed by such researchers as M. Bryl' (2018), T. Kiseleva, Iu. Krasilnikov (2004) and others. Professional communication and communicative competence have been fruitfully studied by O. Dyba (2018), A. Pavlenko and N. Svitajlo (2015), V. Titova (2005), 
I. Schoholieva (2011) and others. The process of professional growth is revealed in the scientific works of D. Bogdanova (2016), N. Kirillova (2012), N. Iaroshenko (2007) and others.

Unresolved issues. Despite considerable amount of scientific works, the issue of studying professional profile of the sociocultural activity manager has not yet received sufficient systematic coverage, since modern research is mainly focused on education and professional training of the sociocultural sphere specialist with pronounced subjective qualities, able to self-expression and self-development. At the same time, the influence of environment on the activity of a modern manager of the sociocultural sphere, increasing his/her competitive potential, ranking of strategic tasks, taking into account the individual specificity of activity, etc., has not gained attention of scientists who worked or continue to work in this field.

Therefore, the need for effective management of the sociocultural sector; the need to organize sociocultural activities in state, sectoral, municipal cultural institutions and public organizations; the importance of creating conditions for development of creative potential of each individual and lack of scientificmethodological base on the specified issue determine the relevance of this work.

\section{Purpose and research methods}

The purpose of the study is theoretical analysis, systematization and generalization of scientific research on substantiation of the professional profile of the modern sociocultural activity manager that will allow to fulfill the requirements of the profession more effectively and be competitive in the harsh market conditions.

The methodological basis of the study is general provisions of the theory of scientific cognition, the principles of science, historicism, objectivity, systematization, unity of theory and practice. The empirical, systematic and axiological approaches, which made it possible to generalize theoretical and practical achievements accumulated by the educational community in the context of studying the professional profile of the nowadays sociocultural activity manager, have become fundamental in the work.

An advantage of the empirical approach, which is based on our own observations, in our opinion, is the opportunity to study the real status of professional activity of the manager of sociocultural sphere, to identify new factors and phenomena in this field, and on this basis to build generalizations, draw conclusions and make practical recommendations. The systems approach is used to highlight directions of creating a professional profile, the components of the modern sociocultural activity manager's professional competence. Axiological approach allows to study socio-cultural phenomena from the point of view of their opportunities to meet the needs of the individual. 
Research methods. To achieve this goal, a set of methods was used, including: analysis, synthesis, systematization, generalization, which allowed to arrange scientific sources and official documents on the state educational policy of Ukraine in the field of sociocultural activity, scientific thought of domestic and foreign researchers; the method of terminological analysis was used in defining the basic concepts of the study; the situational method helped to take into account the specific conditions and circumstances of work of the modern sociocultural activity manager; systems-structural, structural-functional, comparative methods were applied to outline professional profile of the modern sociocultural activity manager in different areas.

Research information base. The obtained results are based on theoretical and methodological developments of domestic and foreign scientists in the field of management and sociocultural activity, monographs and materials of specialized periodicals, proceedings of scientific conferences, and seminars on the studied topics. In the course of research, information from the author's own observations made during teaching of professionally oriented disciplines in the specialty "Management of sociocultural activity" at Sumy State University was also used.

\section{Research results}

Nowadays, the issue of training modern managers and increasing competitiveness of specialists in the field of management at the labor market is becoming extremely important. These processes can also be traced in the sphere of sociocultural activity. Thus, systematization of the conceptual and terminological apparatus of our research needs specifying of its key concepts.

The key concept of our study is the concept of "manager of sociocultural activity", the components of which should be considered in more detail. Despite the widespread use of the term "manager" in the scientific and popular literature, it needs to be defined and clarified.

According to Russian scientists A. Semenov and V. Nabokov (2008), manager is "an organizer of various works within separate units or target audience; a supervisor regarding subordinates; an administrator of any level of management, who organizes work according to modern methods of management activity" (p. 365). In their opinion, a manager occupies different positions in the organization, solves different tasks, performs different functional responsibilities.

According to the definition of a national scientist Yu. Bovtruk (2007), a manager is a person who has passed professional training and received profession of a manager, directs the work of other participants of the organization, coordinates activities of an existing organization and works with the team (p. 86). The scientist $V$. Kravchenko (2013), interprets the concept of "manager" as "a specialist who is professionally engaged in management activity in a 
particular field of enterprise functioning, occupies a permanent management position and is empowered" (p. 20).

The general meaning of the category "manager" has its specific content in combination with the term "sociocultural activity". The definition of sociocultural activity has a fifty-year history and is considered by researchers in several scientific approaches: culturological, pedagogical and socio-philosophical. For example, about fifty years ago, French sociologists J. Dumazedier and M. Imbert (1969) interpreted this notion as conscious, deliberate, organized, even planned acculturation, optimal adaptation to the culture of all segments of the population. Researcher N. Kochubej (2015) believes that the concept of "sociocultural activity" is "the process of involving a person in culture and his/her active integration into this process, which is carried out by society and its social institutions" (p. 17).

The group of Russian scholars T. Kiseleva and Iu. Krasilnikov (2004) believe that sociocultural activity should be considered as a historically conditioned, pedagogically oriented and socially demanded process of transforming culture and cultural values into an object of interaction between the personality and social groups for the benefit of development of every member of society (p. 49).

Professor of Moscow State Institute of Culture N. Iaroshenko (2007) highlights the most important features that make it possible to clearly grasp the essence and specificity of this concept, in particular sociocultural activity: "it is built on the values of culture that determine its content and orientation; implemented in the field of leisure, which determines its organizational and space-time parameters; realized on the basis of activity of its participants, which determines its subjective and active nature" (p. 25).

Thus, generalizing these considerations allows us to provide the essential characteristics of one of the key terms of our study. Consequently, we characterize the manager of the sociocultural activity as a specialist, who is professionally engaged in management activities in the field of culture, the purpose of which is to involve a person in cultural values and to develop him/her actively.

In order to create a professional profile of the nowadays manager of sociocultural activity, we have analyzed the studies of domestic and foreign scientists and regulatory documents. The analysis was conducted in the areas shown in Figure 1.

We find it expedient to consider these areas of study in more detail.

Ensuring high quality of work of the nowadays sociocultural activity manager depends directly on consideration of his/her professional duties and functions, because they provide an opportunity to communicate with foreign colleagues, to establish cooperation in the professional field, to carry out research (in particular, sociocultural diagnostics) aimed at promotion of cultural values in society and so on. 


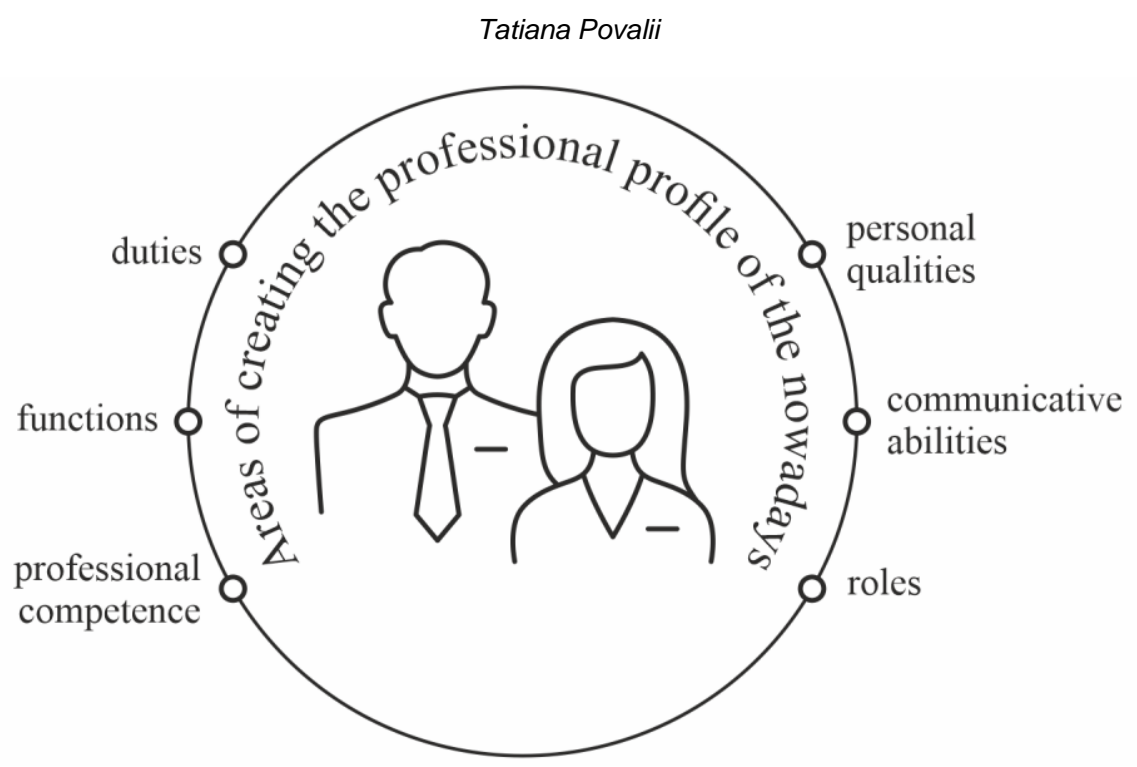

Figure 1. Scheme of the areas of creating the professional profile of the nowadays sociocultural activity manager

Source: own development

The list of the main responsibilities of the sociocultural activity manager, according to job descriptions, includes the following (Monokl, 2019; Myrhorod City Council, 2010; Aktion-MTcFER, 2019): development of strategic tasks of the sociocultural activity of the organization; on the basis of a comprehensive study and analysis of the correlation of demand and supply of creation of current and prospective plans for organization development; provision of a range of services for the sociocultural activities of the population; control over their implementation; development of plans of artistic and entertaining programs taking into account the mode of work of the socio-cultural institutions; independent development of scenarios or involvement of specialists to create scenarios of folk entertainments, mass shows, theatrical holidays, entertaining programs, sports competitions and other demonstration performances, using in their work innovative forms and modern methods of organizing leisure of the population; signing agreements within the scope of their competence with concert and creative organizations to hold theatrical and other performances; cooperation with bodies and institutions of education, sports, social protection; organization of work on advertising and informing the population about sociocultural activities of the organization; attracting sponsors for conducting social and cultural events; preparation of cost estimates and business plans for social and cultural events; promoting self-sufficiency of socio-cultural programs of the organization of cultural and leisure type; maintenance of established reporting; participation in the monitoring of work performed by partners; provision of information and methodological services 
and consultations to socio-cultural institutions with the aim of improving forms and methods of leisure organization; within the scope of its competence to issue orders and other acts, provide instructions compulsory for all employees, etc.

We find it necessary to specify the main functions of the nowadays manager of sociocultural activity, which include planning, organizing, motivating and controlling. Let us consider them in more detail (Kirillova, 2012; Siberian Federal University, 2007):

1) planning - provides clear goal setting, development and implementation of the plan. It includes: content of the activity; financing and other provision; organizational structure; requirements for staff; recruitment, placement and promotion of the personnel; accounting, reporting and control system. There are such types of planning as strategic, tactical and operational. The specified function answers the question: "What?" (What to include in the plan? What to do? What to anticipate? and so on);

2) organizing - creates conditions for effective activity of employees on the basis of coordination of their efforts in the process of sociocultural activity. This function includes authority, delegation and responsibility. The following questions are raised "Who?" and "How?" (i.e. who and how will be able to implement the plan?);

3) motivating - the process of encouraging others to work in order to achieve their goals. As urging for human behavior, motivation requires a clear idea of needs and rewards. Among the current theories of motivation, A. Maslow's hierarchy of needs is the leading one, which includes: physiological needs, needs for safety and confidence in the future, social needs, needs for respect and self-expression;

4) controlling - verification of the tasks fulfillment, arising from strategic and tactical goals of the organization. There are different types of controls in the practice of management, including preliminary, current, final, financial and administrative control. During the control procedure, the following questions should be answered: what have we learned? what should be done differently next time? what is the reason for deviations from the plan? was the control result positive or negative? what conclusions should be drawn to develop new goals?

It should be noted that in addition to the main functions (planning, organizing, motivating and controlling), the manager of the sociocultural branch also performs auxiliary functions in the field of activity (Ignatova et al., 2016, p. 135), in particular: project-technological, communicative, marketing, financial-economic, legal.

The analysis of research of the theorists and practitioners, the state standard, as well as the job descriptions of the managers of sociocultural activity makes it possible to identify the main components of their professional competence. We consider it expedient to elaborate the structure of the defined above competence. 
The first component is sociocultural, technological, organizational, marketing, culturologal, humanitarian, psychological and political knowledge (Dyba, 2018; Monokl, 2019; Ministry of Education and Science of Ukraine, 2019), namely: laws and other normative-legal acts of the Verkhovna Rada of Ukraine concerning sociocultural activity; forms and methods of organizing mass leisure activities of the population; scientific and technical achievements in the field of culture and art; basics of management; psychology of management; basics of economics and management in sociocultural sphere; market conditions for leisure services to the population; basics of marketing; personnel management theory and practice; basics of pedagogy and psychology; forms and methods of advertising campaigns; basics of labor law; rules of internal labor regulations; rules and regulations for occupational safety and health, industrial sanitation and fire protection; paperwork instructions; rules of business etiquette; basic principles of work on the computer; basic professional concepts; fundamental and specific information in the sociocultural field; principles of work of non-profit organizations and the market of cultural services; fundamentals in the field of image science, branding, fundraising, sponsorship, social marketing; in communication theory and practice and so on.

The next component of the professional competence of the nowadays sociocultural activity manager is general and special skills (Timofeev, 2013; Ministry of Education and Science of Ukraine, 2019; Ministry of Education of Russian Federation, 2003), among which: involvement of different segments of the population in the process of production, development, preservation and dissemination of cultural values; formation of economic, political, legal, moral, ecological, aesthetic and physical culture in the population; providing various forms of sociocultural activity with methodological tools; ideological and artistic evaluation of cultural phenomena; constructing socially important contacts, forming a culture of communication; effective use of the art of a living word, visual, technical and other means of ideological and emotional influence; providing methodological and practical assistance to public organizers of sociocultural activity; forecasting, planning and implementation of educational, artistic-creative, game, methodological and administrative-economic activity of cultural and leisure institutions; development and implementation of regional, municipal, departmental and other cultural programs; studying, generalizing, promoting, disseminating and implementing best practices of sociocultural activity; planning and time management; communication in both state and foreign languages; generating new ideas (creativity); identifying and solving problems; teamwork; evaluation and quality assurance of work performed; conducting analysis of economic, environmental, legal, political, sociological, technological aspects of cultural market formation; definition of strategic priorities; use of adequate professional tools for the development and 
operational management of sociocultural projects; distribution of powers and responsibilities based on their delegation; development and implementation of modern forms of sociocultural partnership support; organizing work with various stakeholders in sociocultural activity; the use of modern methods of information processing for organization and management of sociocultural processes; adherence to professional and ethical standards when solving social, cultural and economic problems, etc.

Another component of the professional competence of the sociocultural activity manager is general scientific and professional skills (Timofeev, 2013; Severova, 2014, p. 116; Ministry of Education and Science of Ukraine, 2019), in particular: search and sociological skills - taking into account the needs of different population groups, obtaining scientific knowledge on socio-cultural phenomena; managerial skills - cultural and organizational activities; economic, legal, informational, methodological and organizational support of functioning of institutions, organizations and associations of socio-cultural sphere; decision making and implementation of all management functions; use of information and communication technologies; management of institutions (palaces of culture and art centers, profile studios and circles, libraries, museums, book publishing houses, theaters, research institutions, etc.); preparation and development of managerial decisions in the activity of cultural institutions; resource management of sociocultural activity; communication and game skills - organization of informal communication and recreational games of different population groups; psychological-pedagogical skills - differentiation and individualization of the content and forms of sociocultural activity; creating conditions for self-realization of creative potential of the personality.

In the content of the nowadays sociocultural activity manager's professional competences, personal qualities and communicative abilities are taken into account. According to the scientists (Bogdanova, 2016; Hryhorchuk, 2018, p. 102), the key personal qualities are:

1) leadership qualities - strategic vision, openness, courage, ability to listen to others, attentiveness, criticality, flexibility, sensitivity, result-centeredness, ability to admit one's own mistakes, correct self-esteem, charismaticity, ability to focus, efficiency, competence, erudition, originality, creativity;

2) volitional qualities - ability to work hard, dedication, initiative, independence, determination, courage, vigor, persistence, discipline, efficiency;

3) moral qualities - honesty, civility, benevolence, courtesy, ethics, accuracy, punctuality, confidence, justice, sociability, responsibility;

4) psychological qualities - good memory, rich imagination, ingenuity, sociability, self-control, assertiveness, adaptability, stress resistance, nonconflict, non-standard thinking, patience, developed intuition, self-confidence and confidence in decision-making, striving for constant self-development. 
In our study we find it important to consider communicative abilities of the modern sociocultural activity manager in more detail, as the ability to inform the audience (collective) qualitatively, to present information is a significant component of his/her professional profile. It should be emphasized that successful realization of professional tasks by the sociocultural activity manager is impossible without providing quality of communication (Titova, 2005), which includes: skills of using methods and techniques of creating a trusting and at the same time business atmosphere, establishing channels of receiving and transmitting information, ability to express thoughts clearly and to encourage interlocutor to do the same, ability to listen to the interlocutor and his/her colleagues, conversation skills and ability to persuade, ability to perceive other people as they are and so on.

Studies conducted by domestic and foreign scholars on the content and list of communicative abilities of the modern manager of sociocultural activity, indicate that there is no single approach to their understanding. Despite this, the domestic researcher I. Schoholieva (2011) summarized the approaches to the systematics of communicative abilities and specified their list, which helped to divide them into informational-communicative (bringing the necessary information to the interlocutor), interactive (ensuring effective interaction with all the subjects and contact public) and perceptive abilities (making contact with the interlocutor, ensuring influence on the participants of collective activity, accurate interpretation of information) (p. 12).

In addition, the researchers A. Pavlenko and N. Svitajlo (2015) identified the main components of communication skills (pp. 118-120), which would be considered below in more detail:

1) organizational communications - occur with the authorities (selfgovernment) at the appropriate level, with administration of certain organizations, institutions of socio-cultural sphere, public organizations or creative unions, as well as individual employees, performers in order to form an optimal organizational structure capable of providing implementation of all the components of a planned event, project or target program (is implemented in the form of a letter of request, order, agreement or memorandum);

2) development of program and methodological documentation for the event - the purpose is not only the joint work on the development of the methodology, but also the work of everyone on the adaptation of the methodology to the needs and characteristics of a specific target audience (is carried out in the form of regulatory development, preparation of scientific publications, information materials and methodological guidelines, dictionaries, reference-books);

3) ways of communicating ideas, tasks and principles - the purpose is not only to obtain information about the real state of affairs in a particular 
area (institution, group), not only to inform about the importance of this work, but also to form participants' own vision of this situation, to influence their views and behavior (is performed in the form of a monologue, presentation, dialogue, round table, etc.).

Thus, communicative abilities are not inborn. They can be formed in the process of training and practical activity of the modern manager of sociocultural sphere and cover a much wider range of abilities, knowledge and skills than a somewhat simplified traditional understanding. That is why communication skills stand out among other professional competences.

The next step is to highlight the role of the nowadays manager of the sociocultural activity. There are several varieties of roles that are classified by scholars into three main groups, namely, information, interpersonal, and decision (Bovtruk, 2007, pp. 87-88; Kravchenko, 2013, p. 21-22). The information group includes the following roles: manager-observer (receives necessary information in the socio-cultural field), manager-guide (transfers information to other employees of the organization, conducts informational meetings, distributes reports, etc.) and manager-speaker (informs external stakeholders (meetings, speeches, reports)). The interpersonal group includes the following roles: manager-formal leader (symbolically directs sociocultural activity (holds ceremonies, meets guests, signs legal documents)), manager-leader (supervises and motivates subordinates, performs all responsibilities for sociocultural activity) and manager-mediator (maintains information links both inside and outside the organization). The roles of the decision group were: managerentrepreneur (initiates new projects, new ideas), manager-firefighter (settles conflicts, disputes, adapts to environmental crises), manager-distributor (decides on resource allocation, scheduling, and budgets), and manager-representative (represents the organization at the most important negotiations).

Thus, based on the above mentioned roles of the manager of sociocultural activity, we can outline the main areas of application of his/her professional knowledge and skills. The nowadays manager of sociocultural activity can work in industry, trade, construction, transport and communication, state governance and politics, social sphere, culture, art, sports, hotel, tourist, restaurant business and so on.

\section{Conclusions and discussion}

The results of the study have made it possible to determine the importance of revealing the professional profile of the nowadays sociocultural activity manager and to come to the following conclusions: 
1. The results of the terminological analysis of the key concepts of the studies of domestic and foreign researchers and reference literature allowed to organize the conceptual and terminological apparatus of the research. The concept of the "sociocultural activity manager", defined as a specialist, professionally engaged in management activity in the field of culture, the purpose of which is to involve a person in cultural values and active development.

2. The main areas, in which the professional profile of the nowadays sociocultural activity manager had been created, were distinguished, in particular: duties and functions, professional competence, personal qualities and communicative abilities, roles, fields of professional competence application.

3. Having considered the basic duties and functions of the modern manager of sociocultural activity, the components of his/her professional competence were distinguished, namely: sociocultural, technological, organizational, marketing, cultural, humanitarian, psychological and political knowledge; general and special skills; general scientific and professional skills. It was found out that the content of basic competences took into account both personal qualities (leadership, volitional, moral, psychological) and communication skills (informational-communicative, interactive and perceptive).

4. The roles of the modern manager of sociocultural activity, which had been classified by scientists into three main groups, were revealed, among them: information - manager-observer, manager-guide and manager-speaker; interpersonal - manager-formal leader, manager-leader and manager-mediator; decision - manager-entrepreneur, manager-firefighter, manager-distributor and manager-representative.

Scientific novelty of the obtained results lies in specifying the notion of the manager of sociocultural activity, as a specialist, professionally engaged in management activity in the field of culture, the purpose of which is to involve a person in cultural values and active development; revealing the professional profile of a manager in such areas as duties, functions, professional competence, personal qualities, communicative abilities and roles.

The practical significance of the results obtained lies in the opportunities for the nowadays managers of the sociocultural sphere to use substantiated areas of the professional profile, taking into account the specificity of their activity, which will enable them to compete successfully at the labor market.

Prospects for further scientific exploration in this direction are seen in a thorough study of the issues regarding the use of universal program tools for analyzing the possibilities of professional realization of the nowadays manager of sociocultural sphere in a specific type of activity and at the proper hierarchical level. 


\section{Acknowledgement}

This publication is made in the framework of research work of the Department of Psychology, Political Science and Sociocultural Technologies of Sumy State University within the theme: "Interdisciplinary studies of the aspects of modern society development" (the Project \#01164007770).

\section{References:}

Adolf, V. A. (1998). Professionalnaia kompetentnost sovremennogo menedzhera sotciokulturnoi sfery [Professional competence of the modern manager of the socio-cultural sphere]. Krasnoyarsk: Krasnoyarsk State University (in Russ.).

Aktion-MTcFER (2019). Dolzhnostnaia instruktciia menedzhera po kulturnomassovomu dosugu [Job description of the manager for cultural and leisure activities]. Retrieved from https://vip.1cult.ru/\#/document/118/66503/ (in Russ.).

Bogdanova, D. (2016). Professionalno-vazhnye kachestva menedzherov sotcialnokulturnoi sfery [Professionally important qualities of managers of the sociocultural sphere]. Derzhavinskie chteniia [Derzhavin readings], 2(35), 17-19 (in Russ.).

Bovtruk, Yu. A. (2007). Menedzhment zovnishn'oekonomichnoi diial'nosti [Management of foreign economic activity]. Kyiv: InterRegional Academy of Personnel Management (in Ukr.).

Bryl', M. M. (2018). Menedzher sotsiokul'turnoi diial'nosti iak sub'iekt innovatsij [Manager of socio-cultural activity as a subject of innovation]. Visnyk Kyivs'koho natsional'noho universytetu kul'tury $i$ mystetstv. Seriia: Menedzhment sotsiokul'turnoi diial'nosti [Bulletin of Kyiv National University of Culture and Arts. Series in Management of social and cultural activity], 1, 41-52, doi: 10.31866/2616-7573.1.2018.143386 (in Ukr.).

Dumazedier, J., \& Imbert, M. (1969). Espace et loisir dans la société française d'hier et de demain [Space and leisure in French society of yesterday and tomorrow]. Revue française de sociologie [French Review of Sociology], 10-3, 377-378 (in Fr.).

Dyba, O. P. (2018). Komunikatyvna kompetentnist' iak skladova profesijnosti menedzhera kul'tury [Communicative competence as a component of the culture manager's professionalism]. Bibliotekoznavstvo. Dokumentoznavstvo. Informolohiia [Library Science. Documentary science. Informology], 3, 103-111, doi: 10.32461/2409-9805.3.2018.150946 (in Ukr.).

Hryhorchuk, T. V. (2018). Formuvannia profesiohram menedzheriv sotsiokul'turnoi sfery [Formation of professiograms of managers of sociocultural sphere]. Visnyk Kyivs'koho natsional'noho universytetu kul'tury i mystetstv. Seriia: Menedzhment sotsiokul'turnoi diial'nosti [Bulletin of Kyiv National University of Culture and Arts. Series in Management of social and cultural activity], 2, 90-106, doi: 10.31866/2616-7573.2.2018.149468 (in Ukr.). 
Iaroshenko, N. N. (2007). Istoriia i metodologiia teorii sotcialno kulturnoi deiatelnosti [History and methodology of the theory of socio-cultural activity]. Moscow: Moscow State University of Culture and Arts (in Russ.).

Ignatova, I. B., Donskaia, T. K., \& Pliushkina, N. E. (2016). Spetcifika professionalnoi deiatelnosti menedzhera sotciokulturnoi sfery [The specifics of the professional activity of the manager of the sociocultural sphere]. Professionalnoe obrazovanie $v$ Rossii $i$ za rubezhom [Professional education in Russia and abroad], 3 (23), 133-136 (in Russ.).

Kirillova, N. B. (2012). Menedzhment sotciokulturnoi sfery [Management of sociocultural sphere]. Ekaterinburg: Ural University Publishing (in Russ.).

Kiseleva, T. G., \& Krasilnikov, Iu. D. (2004). Sotcialno-kulturnaia deiatelnost [Sociocultural activity]. Moscow: Moscow State University of Culture and Arts (in Russ.).

Kochubej, N. V. (2015). Sotsiokul'turna dial'nist' [Sociocultural activity]. Sumy: Universytets'ka knyha (in Ukr.).

Kravchenko, V. O. (2013). Menedzhment [Management]. Odesa: Atlant (in Ukr.).

Lokshyn, V. S. (2011). Profesijna kompetentnist' menedzheriv sotsiokul'turnoi sfery v konteksti fenomenolohichnykh skladovykh poniatijnoho aparatu [Professional competence of socio-cultural managers in the context of phenomenological components of the conceptual apparatus]. Molod' $i$ rynok [Youth and the market], 1(72), 59-65 (in Ukr.).

Ministry of Education and Science of Ukraine (2019, June 20). Standart vyschoi osvity za spetsial'nistiu 028 «Menedzhment sotsiokul'turnoi diial'nosti» haluzi znan' 02 «Kul'tura ta mystetstvo» dlia pershoho (bakalavrs'koho) rivnia vyschoi osvity [Higher education standard of Ukraine in specialty 028 "Management of social and cultural activity" of the field of knowledge 02 "Culture and art" for the first (bachelor) level of higher education]. Retrieved from https://mon.gov.ua/storage/app/media/vishchaosvita/ zatverdzeni\%20standarty/2019/06/25/028-menedzhment-sotsiokulturnoidiyalnosti-bakalavr.pdf (in Ukr.).

Ministry of Education of Russian Federation (2003, February12). Standart vysshego professionalnogo obrazovaniia $v$ oblasti kultury $i$ iskusstva po spetcialnosti «Sotcialno-kulturnaia deiatelnost» [The standard of higher professional education in the field of culture and art in the specialty «Socio-cultural activity»]. Retrieved from https://eduscan.net/standart/071401 (in Russ.).

Monokl (2019). Posadova instruktsiia Dyrektora tsentru kul'tury i dozvillia, tsentru dozvillia, naukovo-metodychnoho tsentru, budynku narodnoi tvorchosti [Job description of the director of the center of culture and leisure, leisure center, scientific-methodical center, house offolk art]. Retrieved from https://www.borovik.com/index_instruction.php? Gins=lcli\&lang_i=1 (in Ukr.).

Myrhorod City Council (2010). Posadova instruktsiia nachal'nyka viddilu kul'tury i turyzmu [Job description of the Head of the Department of 
Culture and Tourism]. Retrieved from http://myrgorod.pl.ua/files/docs/ Publichna_inform/Posadovi_instrukcii/posadova_kultura.pdf (in Ukr.).

Pavlenko, A. V., \& Svitajlo, N. D. (2015). Komunikatsijnyj potentsial hendernoho audytu diial'nosti VNZ (na prykladi Sums'koho derzhavnoho universytetu) [Communication potential of gender audit of university activity (on the example of Sumy State University)]. Henderna paradyhma osvitn'oho prostoru [Gender paradigm of educational space], 2, 116-123, doi: 10.31812/ gender.v2i2.2188 (in Ukr.).

Schoholieva, I. V. (2011). Formuvannia komunikatyvnykh umin' majbutnikh menedzheriv turyzmu u protsesi vyvchennia profesijno oriientovanykh dystsyplin [Formation of communicative skills of future tourism managers in the process of study of professionally oriented disciplines]. Avtoreferat kandydats'koi dysertatsii [Abstract of thesis candidate's dissertation]. Kirovohrad: Volodymyr Vynnychenko Kirovohrad State Pedagogical University (in Ukr.).

Semenov, A. K., \& Nabokov, V. I. (2008). Osnovy menedzhmenta [Management basics]. Moscow: Dashkov and Ko (in Russ.).

Severova, L. A. (2014). O kompetentnostnom podkhode v sisteme obrazovaniia menedzherov sotcialno-kulturnoi deiatelnosti v VUZakh kultury i iskusstv [On the competency-based approach in the education system of managers of socio-cultural activities at the universities of culture and the arts]. Kultura i obrazovanie [Culture and education], 1(12), 110-118 (in Russ.).

Siberian Federal University (2007). Teoriia i praktika sotciokulturnogo menedzhmenta [Theory and practice of sociocultural management]. Krasnoyarsk: Avtor (in Russ.).

Timofeev, D. (2013). Kulturologiia dosuga [Cultural studies of leisure]. Retrieved from https://sites.google.com/site/zadaniaskd/diplomnye/ kulturologiadosuga (in Russ.).

Titova, V. B. (2005). Kommunikativnaia kultura kak uslovie uspeshnosti deiatelnosti spetcialista sotcialno-kulturnoi sfery [Communicative culture as condition of success of activity of specialist of sociocultural sphere]. Kandidatskaia disertatciia [Candidate's dissertation]. St. Petersburg: St. Petersburg University of the Humanities and Social Sciences (in Russ.). 